Lutovac, S., \& Kaasila, R. (2018). Future Directions in Research on Mathematics-related Teacher

Identity. International Journal of Science and Mathematics Education, 16(4), 759-776.

https://doi.org/10.1007/s10763-017-9796-4

\title{
Future Directions in Research on Mathematics-related Teacher Identity
}

\author{
Sonja Lutovac* and Raimo Kaasila* \\ *Faculty of Education, University of Oulu, P.O. Box 2000, Finland-90014
}

\begin{abstract}
Mathematics education research has placed great emphasis on teacher identity, examining both pre- and in-service teachers, and within these cohorts, specialised mathematics teachers and non-specialists such as elementary teachers. Extensive research has already been done; hence, this paper discusses possible future directions for research on teacher identity in mathematics education. Among other issues, we highlight that general education research on identity has infrequently informed research on mathematics-related teacher identity. This limits the transfer of knowledge but also isolates mathematics education from general education research. We suggest that connecting these lines of research and their findings may not only strengthen mathematics education research and mathematics teaching and learning but also contribute to less isolation within the discipline as a whole.
\end{abstract}

Keywords: future research, mathematics education, research overview, teacher identity

\section{Introduction}

Since the early 2000s, the concept of teacher identity has gained prominence in education research. Several review papers have synthesised the vast research on the topic, demonstrating its popularity and significance for teaching and learning. Beijaard, Meijer and Verloop (2004) provided comprehensive insights into teacher identity while highlighting the lack of clarity in its definitions. Beauchamp and Thomas's (2009) overview highlighted how the complexities of the concept present obstacles to its study. The authors also emphasised the importance of incorporating teacher identity into teacher education. Izadinia (2013) reviewed studies pertaining specifically to pre-service teachers' identities. The author criticised the recent research for highlighting overly positive results and warned against an unrealistic and simplistic understanding of the complex process of identity development. These works have demonstrated that one of the central reasons for research on teacher identity is its link and relevance to practice - in other words, for teaching and learning (see also Watson, 2006). In addition, these studies have clearly illustrated the link between the identity and other frequently investigated concepts, such as narrative, reflection, agency, emotions and the contextual factors that shape teacher identity (Beauchamp \& Thomas, 2009; Beijaard et al., 2004; Izadinia, 2013; see also Rodgers \& Scott, 2008).

Recent research has shown that teacher identity is not a static trait but rather a dynamic construct, changing over time and across the different contexts in which teachers operate (e.g. Flores \& Day, 2006; Rodgers \& Scott, 2008). Teacher identities are also multi-faceted (Cooper \& Olson, 1996; Gee, 2001). Researchers have often distinguished between preservice teachers' identities and experienced teachers' identities, as well as between the personal and professional aspects of teacher identity (Beijaard, Verloop, \& Vermunt, 2000). We can also speak of the teacher identities associated with different subject disciplines, such 
as mathematics (Drake, Spillane, \& Hufferd-Ackles, 2001; Hobbs, 2012a; Spillane, 2000). Arguably, such subject-specific identities provide insight into who teachers know themselves to be in the context of mathematics. Mathematics as a subject has notoriety as being difficult and a source of struggle for many students, but it often also presents a challenge for the preand in-service elementary teachers who teach it (e.g. Grootenboer, 2006). For example, research on affect in mathematics education has documented many of these challenges (Di Martino \& Zan, 2010; Jones, Brown, Hanley, \& McNamara, 2000; Kaasila, Hannula, Laine, $\&$ Pehkonen, 2008). The challenges of learning and teaching mathematics, paired with the notion that we teach who we are (Hamachek, 1999), has naturally led in an increase in the number of publications addressing teacher identity in mathematics education research. Alongside many journal articles, some seminal books (Black et al., 2009; Brown \& McNamara, 2011) and literature reviews (Darragh, 2016) have also been published. These publications have revealed the significance of the concept for the field, whether as an object of investigation (Hodges \& Cady, 2012; Lutovac \& Kaasila, 2011, 2014; van Zoest \& Bohl, 2005) or as a lens through which to understand various learning- and teaching-related constructs (Boylan \& Woolsey, 2015; Goos, 2005; Ma \& Singer-Gabella, 2011).

Because extensive research has already been done, including several of our own studies (Kaasila, 2007; Lutovac \& Kaasila, 2011, 2012, 2014), we argue that more insight is needed into the directions toward which research on mathematics-related teacher identity could develop. In this paper, we first briefly summarize the research on mathematics-related teacher identity, focusing on 40 studies that were published between 2000 and 2015 in peer-reviewed scholarly journals. We wish to emphasize that this is not a literature review; instead, we selected 40 studies with which to outline the research field and discuss the current issues on the topic of teacher identity in mathematics education. We conclude with a discussion of future directions for mathematics education research in this area. The research question that guided this paper is: What can we learn from recent studies about the directions toward which research on mathematics-related teacher identity could develop?

\section{Method}

We examined the leading studies on teacher identity, which were published in leading journals in the domains of mathematics and teacher education. In order to obtain the studies that would be included or excluded from detailed analysis, we used the Education and Social Sciences and ERIC (ProQuest) databases to look up the keywords 'identity', 'mathematics' and 'teacher' according to the following three-step search process: first, we searched for keywords in the title ( $=\mathrm{TI})$; second, we searched for keywords in the author-provided abstract $(=\mathrm{AB})$; third, we searched for keywords in the identifiers (keywords $=\mathrm{IF}$ ) and subject headings $($ all $=\mathrm{SU})$. The additional search criteria were: the studies had to be written in English and published between 2000 and 2015 in peer-reviewed scholarly journals. Hence, conference proceedings, books and dissertations were excluded. The search was conducted in February 2016.

We noticed that publications identified by titles only (26 studies) presented a decidedly narrow view of the previous research, as the titles of many relevant studies on teacher identity in mathematics education do not necessarily include all three keywords. Conversely, searching for publications based on author-provided abstracts (142 studies) produced results that were far too broad. Many of these studies did not fit the scope of this paper as their central foci were not necessarily on identity itself. An additional challenge was that many authors connected their topics to identity in their abstracts but did not address the concept 
further. Our initial results also included studies that did not belong to the field of mathematics education. Therefore, in the third step, we found that searching identifiers (45 studies) and subject headings (35 studies) provided the most precise results. After eliminating duplicates, however, we still had multiple studies that did not fit the focus of this paper. Most frequently, this was because these studies did not deal with teacher identities but with student identities; these were excluded from further analysis accordingly. We also decided to look only at those studies that explored the identities of pre- and in-service teachers, disqualifying studies on higher education teachers and mathematics coaches (see Chval et al., 2010). Based on this third step search, and after applying the exclusion criteria and eliminating duplicates, we obtained 32 studies.

We then repeated the third step search and cross-checked our primary results with Academic Search Premier (EBSCO) and Scopus. This resulted in an additional eight studies, which left us with a total of 40 studies to be examined more closely. We wish to note here that some relevant studies might have been excluded from this review because they did not meet the aforementioned selection criteria. We are aware that researchers use various terms that correspond with or relate to the concept of identity, such as subjectivity, identifying or becoming. However, because this paper focuses specifically on identity, we did not take into account studies employing directly or indirectly related concepts. Finally, the selected studies and their theoretical underpinnings were carefully analysed.

\section{What We Know About Mathematics-related Teacher Identity}

\section{Terminology}

The research on teacher identity in mathematics education has addressed identities of preand in-service teachers. This includes two cohorts of teachers who teach mathematics in schools: mathematics specialist teachers and elementary teachers. Researchers have used different terms when discussing these identities. Kaasila et al. (2008) and Lutovac and Kaasila $(2011,2014)$ used the term 'mathematical identity' to explore pre-service elementary teacher identity in the context of mathematics. Van Putten et al. (2014) used the term 'professional mathematics teacher identity', which refers to those who specialise in teaching mathematics. Van Zoest and Bohl (2005), on the other hand, referred to 'mathematics teacher identity', which includes those teachers who do not specialise in mathematics but who teach it in elementary schools. Although the last term provides some level of uniformity for all individuals who teach or will eventually teach mathematics, the vast body of research has demonstrated great differences between the identities of specialist and non-specialist mathematics teachers (Black, Solomon, \& Mendick, 2009). For instance, elementary teachers often do not personally relate with the subject and hence do not identify themselves as mathematics teachers but rather 'teachers of mathematics', the term used by Hodgen and Askew (2007). Because we discuss research on the teacher identities of all those who teach mathematics and are aware of the differences between the two cohorts of teachers; we believe the term 'mathematics-related teacher identity' to be the most appropriate.

\section{Theoretical Perspectives}

Theoretically, the majority of studies on mathematics-related teacher identity employ a sociocultural perspective, such as that which is informed by Lave and Wenger's work on situated learning and Wenger's (1998) work on communities of practice. This perspective usually equates learning with developing an identity in communities of practice (Bennison, 2015; 
Essien, 2014; Hodgen \& Askew, 2007; Hodges \& Cady, 2012; van Zoest \& Bohl, 2005). Van Zoest and Bohl (2005) summarised Wenger's notion of identity as

the 'who we are' that develops in our own minds and in the minds of others as we interact with them. It includes our knowledge and experiences, but also our perceptions of ourselves (i.e., our values, beliefs, desires, motivations, and selfidentifications), others' perceptions of us, and our perceptions of others' perceptions of us that develop as we participate in communities with one another. (p. 320)

In addition, some studies have applied other frameworks, such as Lev Vygotsky's culturalhistorical activity theory (Owens, 2014), Dorothy Holland and colleagues' figured worlds (Ma \& Singer-Gabella, 2011; Williams, 2011), Basil Beinstein's concept of pedagogic identity (Pausigere \& Graven, 2013), Jaan Valsiner's theory of human development (see Goos, 2005), John Dewey's framework of aesthetic experience (Hobbs, 2012b) and dialogical self-theory (Pipere \& Mičule, 2014), and Sfard and Prusak's (2005) notion of narrative identity (see Bjuland et al., 2012; Gujarati, 2013; Wassel, 2006).

Another theoretical perspective was also post-structuralism and the idea of identity as revolving around the meaning of language; in it, identity is understood as fragmented, multifaceted, contingent and partial (de Freitas, 2008) and to develop in various, often conflicting discourses (Llewellyn, 2009). Interpreting Michel Foucault's views, Walshaw (2013) viewed discourses as unwritten rules, "sketching out ways of being in the world, defining the possibilities, as well as the limits, of meaningful existence" (p. 102). In other words, this perspective is founded on the idea that discourses create reality and position people in their identities. Hence, discourses have the power to prescribe one's identity and invite further processing, such as positioning, categorisation, negotiation and normalisation (de Freitas, 2008; Skog \& Anderson, 2015; Walshaw, 2013). These processes help us to understand how identity is shaped within various social structures. Besides widely applying Foucault's work, researchers have drawn on Paola Valero's and Rochelle Gutierrez's discussion of sociopolitical perspectives in mathematics education, as well as contributions of Judith Butler, Ernesto Laclau and Chantal Mouffe, Gilles Deleuze and Felix Guattari and Margaret Walshaw.

Many studies have been built on several interrelated areas of research, including education research (van Putten, Stols, \& Howie, 2014; Kasten, Austin, \& Jackson, 2014; Spillane, 2000) or mathematics education research that focuses on affect (Leatham \& Hill, 2010; Kaasila et al., 2008; Kaasila, Hannula, \& Laine, 2012). Narrative was also used as a metatheoretical approach (Drake et al., 2001; Lutovac \& Kaasila, 2011; McCulloch, Marshall, DeCuir-Gunby, Caldwell, \& Ticola, 2013); such studies not only employed narrative methodologies but also constructed theoretical frameworks rooted in Jarome Bruner's work on narrativity and narrative identity as discussed by Dan McAdams and Paul Ricoeur. Within this approach, individuals are understood as storytellers and their identities are either constructed through stories or defined as stories.

\section{Definitions}

In accordance with their differing theoretical frameworks, the studies in the field have presented a variety of definitions of teacher identity. For example, Van Putten et al. (2014) defined teacher identity as "the crossroads between the personal and the social self, the "who I am at this moment" (p. 370). McCulloch et al. (2013) equated identity with the stories individuals hear and tell about themselves, while de Freitas (2008) saw identity as "socially 
constructed and confined by classroom discourse" (p. 44). Most definitions were borrowed from elsewhere and drew on established theories, such as Lave and Wenger's situated learning, Wenger's community of practice, or Foucault's work on discourse, knowledge and power. Much of the research has also been influenced by single studies, such as the widely cited work of Sfard and Prusak (2005). In a recent literature review on identity in mathematics education research, Darragh (2016) extensively tackled the definitions of identity, categorizing them as participative, narrative, discursive, psychoanalytic and performative. In the absence of a clear definition of teacher identity (see also Beauchamp \& Thomas, 2009; Beijaard et al., 2004), we take this uncertainty as a given. Like many other researchers, we see identity as a complex construct that subsumes many other complex constructs, which makes defining it a complicated, and even impossible, task (van Zoest \& Bohl, 2005). However, every study on mathematics-related teacher identity still has to respond to Sfard and Prusak's (2005) call to provide at least a working definition, which all of the studies analysed in this paper have done.

\section{Issues and Findings}

Based on our examination of the studies that addressed mathematics-related teacher identity, we find that most have considered multiple themes, such as a) theoretical models and what constitutes identity; b) the contextual factors (including subject context) in teacher identity and its development; c) the opportunities for identity development during pre- or in-service teacher education; d) affective relationships with mathematics and changes in teacher identity; e) power, social justice, gendered discourses and race in identity and its development; f) the link between identity and teaching practices.

Theoretical models and what constitutes identity. Many studies have tackled the constituents of identity; as a result, some have also provided theoretical models for understanding identity (e.g. Boylan \& Woolsey, 2015; Bennison 2015; Van Putten, Stols, \& Howie, 2014, Pausigere \& Graven, 2013; Leatham \& Hill, 2010; Owens, 2008; van Zoest \& Bohl, 2005). Bennison (2015) spoke of 'identity-embedded-in-numeracy', de Frietas (2008) discussed the identity of mathematics 'mastery', Spiltler (2012) explored a literacy identity within the context of teaching mathematics and although Owens (2008) distinguished teacher identity from what she called 'identity as a mathematical thinker', we can see that the latter aspect may in fact form a vital part of teacher identity. Boylan and Woolsley (2015) discussed the stable and fluid aspects of 'social justice teacher identity' and linked these to corresponding pedagogies, such as those of discomfort and inquiry on the one hand and compassion and respect on the other, proposing that these pedagogies should be balanced in teacher education. Van Putten, Stols and Howie (2014) argued that three aspectsmathematics specialist, teaching-and-learning specialist and carer-constitute a teacher's identity as a mathematics teacher. Finally, Drake et al. (2001) argued for the need to understand teachers' learner identities, as these are closely linked to how teachers learn to teach and hence who they are as teachers (see also Kaasila et al., 2008; McCulloch et al., 2013).

The contextual factors in teacher identity and its development. Several studies have dealt with the contextual factors (including subject context) in teacher identity and its development (de Freitas, 2008; Drake et al., 2001; Goos \& Bennison, 2008; Hobbs, 2012a,b; Hodges \& Cady, 2012; Kasten, Austin, \& Jackson, 2014; Lutovac \& Kaasila, 2014; Owens, 2014; Spillane, 2000; van Zoest \& Bohl, 2005). Among them, many studies have emphasised the context-dependent status of teacher identity, particularly regarding the subject matter that 
teachers teach (Drake et al., 2001; Spillane, 2000) and the education level at which they teach mathematics (Kasten, Austin, \& Jackson, 2014; Leatham \& Hill, 2010). Hobbs (2012b) built on Dewey's work by discussing how subject-context differences influence teachers' approaches to teaching. This framework allowed for the examination of both the cognitive and affective dimensions of teaching, as reported by three secondary mathematics teachers; Hobbs concluded that teachers' experiences shape their engagement with the subject they teach. Due to the finding that some pre-service teachers identified more with the grade level at which they teach than with mathematics as a subject, Kasten et al. (2014) recommended that teacher education settings focus on assisting in the development of both their teacher identities in general and specifically, mathematics teacher identities.

Particularly in socio-cultural perspectives, teacher identity was found to develop in interaction with others within various contexts or learning communities (Bjuland, Cestari, \& Borgersen, 2012; van Zoest \& Bohl, 2005), online communities (Goos \& Bennison, 2008), professional development communities (Hodges \& Cady, 2012) and racial and cultural communities (Clark, Badertscher, \& Napp, 2013), as well as in relation to education policy (Pausigere \& Graven, 2013; Woolhouse \& Cochrane, 2015). Van Zoest and Bohl (2005) suggested that pre-service teacher education communities should be strongly intertwined, as this would better assist pre-service teachers in their own learning to become teachers.

Identity development during pre- or in-service teacher education. Overall, most of the studies addressed the opportunities for identity development during pre- or in-service teacher education (Bjuland et al., 2012; Chronaki \& Matos, 2014; Essien, 2014; Hossain et al., 2013; Kaasila et al., 2008; Kaasila et al., 2012; Llewellyn, 2009; Lutovac \& Kaasila 2011; 2014; Neumayer Depiper, 2013; Spitler, 2012; Wassell, 2006), including the tensions that can occur during this process, as well as the possibility for change and its facilitators (Hobbs, 2012a; Hodgen \& Askew, 2007; Hodges \& Cady, 2012). In the context of out-of-field teaching, i.e. teaching a subject without the qualifications to teach it, Hobbs (2012b) showed that contextual factors, support mechanisms and teachers' personal resources all influence the development of teacher identity. In addition, teacher knowledge was recognised as being determined by whether teachers feel in- or out-of-field. Essien (2014) pointed out the need for greater awareness of the identities that teacher education assists in developing. Unfortunately, arguably, pre-service teacher education often does not provide opportunities for students to develop the versatile identities needed for their future profession. Similarly, some researchers spoke about the emerging concept of identity work (Chronaki \& Matos, 2014; Hossain, Medick, \& Adler, 2013) and called for the better preparation of teachers for teaching mathematics under various socio-political constraints (Neumayer-Depiper, 2012). Chronaki and Matos (2015) suggested that understanding teacher identity work may also help us understand the discourses of technology use in mathematics education and the potential for change in terms of identity. Finally, it has been suggested that identity development and identity work may be facilitated by challenging multiple discourses in the context of mathematics (de Freitas, 2008), expanding the repertoire of discourses available to students during teacher education (Skog \& Andersson, 2015) and encouraging a strong focus on selfreflection (Hossain et al., 2013; Leatham \& Hill, 2010). On the other hand, NeumayerDepiper (2013) questioned the possibility of facilitating identity work in teacher education.

Affective relationships with mathematics and the process of change in teacher identity. Some studies addressed affective relationships with mathematics and changes in teacher identity (Drake et al., 2001; Hodgen \& Askew, 2007; Kaasila et al., 2008; Kaasila et al., 2012; Lutovac \& Kaasila, 2011, 2014). These studies tackled changes in emotions (Hodgen 
\& Askew, 2007); changes in pre-service teachers' views of mathematics (Kaasila et al., 2008; Lutovac \& Kaasila, 2011) or changes in pre-service teachers' identity talk (Kaasila et al., 2012). Some of these discussed the contextual factors that promote or hinder these changes in pre-service elementary teachers who report having a negative relationship with mathematics as a result of negative experiences during their school years (see also Lutovac \& Kaasila, 2014). Hodgen and Askew (2007) explored the potential for one elementary teacher to rebuild her emotion-laden relationship with mathematics by engaging in professional development; their findings suggest that teachers may reconnect with mathematics throughout their careers, as long as the affective dimension of teacher education is taken into consideration. Within this group, some studies specifically addressed the role of teachers' narratives in identity development (Bjuland et al., 2012; Drake et al., 2001; Lutovac \& Kaasila, 2011, 2014; McCulloch et al., 2013; Wasell, 2006; Williams, 2011). To a certain extent, most of these studies considered the biographical details of their research subjects and their links to identity. They highlighted that intentional reflection via autobiographies, course readings, group discussions on personal experiences with mathematics and reflections on possible teacher selves (Kaasila et al., 2008; Lutovac \& Kaasila, 2011, 2014; McCulloch et al., 2013) may be particularly meaningful for pre-service teachers' process of change and their evolving teacher identities. Similarly, Andersson (2011) suggested that teachers should not be viewed as static but capable of dynamic learning over time, which is supported by reflecting and narrating their own experiences.

Power, social justice, gendered discourses and race in identity and its development. Post-structural studies have often addressed the issues of power, social justice, gendered discourses and race in identity and its development (Boylan \& Woolsey, 2015; de Freitas, 2008; Llewellyn, 2009; Walshaw, 2013). These studies have been particularly successful in exploring inclusion and exclusion and social inequalities in the context of mathematics education (Boylan \& Woolsey, 2015; de Freitas, 2008; Hossain, Mendick, \& Adler, 2013; Walshaw, 2013). For example, Walshaw (2013) discussed one pre-service teacher's identity construction through social interaction during a teaching practicum; the author argued for the need to understand how power and discourses shape and constrain certain identities, which are central to (in)equity in mathematics education; therefore, awareness of power and discourses should be incorporated into teacher education. Similarly, de Freitas (2008) challenged pre-service mathematics teachers' beliefs about the innate ability to do mathematics, showing that critical reflection and the resultant self-awareness, especially through narratives of personal experiences, may help teachers to become more aware of the contextual factors at work in their identity development, particularly how school mathematics reinforces their 'mathematics mastery identities'. Finally, in an elementary mathematics context, Llewellyn (2009) showed how competing discourses may either facilitate or hinder pre-service teacher' identities and warned against the dangers of gendered discourses enacted through labelling.

The link between identity and teaching practices. The final group of studies addressed the link between identity and teaching practices (Andresson, 2011; Clark et al., 2013; Goos, 2005; Gujarati, 2013; Hobbs, 2012b; Ma \& Singer-Gabella, 2011; van Putten et al., 2014). Goos (2005) discussed the dynamics between the teaching practices, the context within which they occur and the development of one beginning mathematics teacher's identity in the context of teaching with technology. An inverse relationship between identities and teaching practices has been displayed in Gujarati's (2013) study: even though teachers had a somewhat negative view of themselves in relation to mathematics, their teaching practices portrayed a more positive picture. Similarly, Van Putten et al.'s (2014) study investigated 
pre-service mathematics teachers' self-perceived and actualised identities and revealed some interesting incongruities between pre-service mathematics teachers' espoused and enacted theories. Finally, Andersson (2011) explored one in-service mathematics teacher's development, resulting not only in changes to her teaching practices but also in her identity.

\section{Future Directions in Research on Mathematics-related Teacher Identity}

\section{Balancing Individual and Social Perspectives}

Despite the acknowledgement of social orientation in mathematics education research, we were surprised by the absence of individual or psychological emphases. Both socio-cultural and post-structural perspectives focus more on social practices and structures, thereby considering an individual's inner world to be of minor importance. In our view, this highlights the misunderstanding of the social turn in mathematics education research (Lerman, 2013). Although an individual's identity is greatly shaped by the social contexts in which he or she evolves, we believe that by neglecting the individual, i.e. how one thinks and feels and who one is, is at odds with the core concept of identity itself. The current lack of individual emphasis also poses an important question: to what extent can such findings inform us about how to assist pre- and in-service teachers in their identity development? Hence, we advocate for a more balanced psychosocial approach akin to Boylan and Woolsey's (2015) "psychosocial arena in which multiple identities are shaped and interrelate" (p. 63), or Hodges and Cady's (2012) "dual focus on the individual's thinking and the influence of collective experiences in understanding the construction of an identity as a mathematics teacher" (p. 114).

\section{Linking the Research on Cognition and Affect with the Research on Identity}

Skott, van Zoest and Gellert (2013) suggested that identity can be conceptualised as the intersection of affect and cognition; however, our analysis shows that most studies lacked an explicit connection to research on either affect or cognition. By explicit connection, we mean that which builds on the body of research conducted in either domain, theoretically and analytically (e.g. Gujarati, 2013; Kaasila et al., 2008; Pipere \& Mičule, 2014). For the most part, research on affect was more likely to be taken into account in studies on pre-service elementary teachers' identities (e.g. Drake et al., 2011; Hodgen \& Askew, 2007; Kaasila et al., 2008; Kaasila et al., 2012; Lutovac \& Kaasila, 2011, 2014). Given that elementary teachers tend to have more emotional struggles in relation to mathematics than mathematics teachers, this emphasis seems justifiable. Nevertheless, only two studies explicitly took into account the affective aspect of mathematics teachers' identities: one effectively combined the research on cognition and affect by addressing subject-matter expertise and the component of caring in the mathematics teachers' identities (van Putten et al., 2014) and the other drew extensively from research on mathematics-related affect (Pipere \& Mičule, 2014). For out-offield-teachers' identities, Hobbs (2012b) explored the roles of knowledge and aesthetics in their identification process.

Darragh (2016) warned against understanding identity as a 'catch-all term for affect'. However, considering that studies on cognition and affect have a long research tradition and have contributed greatly to the body of knowledge in mathematics education research, taking them more explicitly into account would offer a more comprehensive understanding of teacher identity and directly link identity to learning and teaching (see e.g. Grootenboer \& Zevenbergen, 2008; Jones et al., 2000). Moreover, we also call for a more explicit 
exploration of emotions in mathematics-related teacher identity development, one that moves beyond generalities and provides empirical data on the links between emotions and identity. This is important because we know that mathematics evokes strong emotions from students and teachers alike; such emotions present great obstacles to professional development and change (e.g. Hodgen \& Askew, 2007).

\section{Linking Mathematics Education Research with General Education Research}

Our next observation relates to the origin of the theoretical frameworks that these studies used. A cursory look at the cited references shows that researchers built their theoretical frameworks from (1) research specific to mathematics education, (2) research specific to general education or (3) research borrowed from other fields. While some studies, particularly those that included eclectic theoretical perspectives, built heavily on education theoretical frameworks, many valuable publications on identity from the field of general education were underrepresented in the citations of the reviewed studies. Hence, it appears that general education research on identity infrequently informs research on mathematicsrelated teacher identity. In other words, only a few of the studies (e.g. Hobbs, 2012b) cited seminal education publications on teacher identity mentioned in the introductory text of this paper. Furthermore, only two studies (Pipere \& Mičule, 2014; van Putten et al., 2014) actually utilised the teacher identity framework developed by Beijaard et al. (2000). While we value all of the contributions and are aware that researchers have the liberty to choose which theoretical perspectives support their work, the aforementioned omission makes us question why such important frameworks from the domain of education have been disregarded. Assuming that mathematics education is as much about education as it is about mathematics, it is reasonable to expect that the findings from general teacher identity research will be relevant to research into mathematics-related teacher identity. Unfortunately, we see that mathematics education researchers have not taken full advantage of these findings, as evidenced by poor cross-referencing. Moreover, failure to take into account theories and findings from the education literature creates a gap between the general education and subject-specific education domains such as mathematics. It positions mathematics education research as different, thereby hindering its inclusion in wider education research discussions.

We know that mathematics is often seen different from other subjects; it is even seen as of greater importance and considered to be both powerful and intimidating (Black et al., 2009; Boaler, 2015; Brodie, 2011). This influences how students learn mathematics, how they feel about themselves in relation to mathematics and how they are seen by others in this context, all of which influence identity. In our view, akin to the discourses surrounding mathematics as an elite subject (e.g. Boaler, 2015), the isolated research practices to which mathematics education researchers seem to subscribe position mathematics education research as an elite domain as well. This reinforces the perceptions of the discipline's 'specialness' held by other educators. Hence, it is necessary for mathematics education researchers to engage in wider discussions; while they are likely to be mathematicians or mathematics specialists and more familiar with subject-specific research, theories and applications, we believe that all researchers should try to minimize isolated research practices.

\section{Linking Research on Mathematics Teachers with Research on Elementary Teachers}

With few exceptions, there was a clear disconnect between the research on mathematics teachers' identities and the identities of elementary teachers in relation to mathematics. We 
believe that this disconnect not only limits the transfer of knowledge but also isolates mathematics research from general education research, as previously discussed. This disconnect also gives a fragmented view of the teachers who teach mathematics. That said, there are some major differences between the mathematics-related teacher identities of these two cohorts of teachers which should not be overlooked. These differences include variations in subject-matter expertise, levels of teaching confidence and bonds with the subject (Black et al., 2009; Hodgen \& Askew, 2007; Jones et al., 2000; Pipere \& Mičule, 2014). For example, in van Putten et al. (2004), pre-service mathematics teachers talked about their love and appreciation for mathematics. In our experience, the vast majority of pre-service elementary teachers do not relate to these descriptors and do not use them to describe their relationships with mathematics. Therefore, researchers should keep in mind that what holds true for mathematics teachers does not necessary hold true for elementary teachers who teach mathematics, and vice versa.

Moreover, caution should be exercised in the precise use of terms for labelling these identities, as well as in acknowledging their differences. For example, Hobbs (2012) revealed that for specialised mathematics teachers, the 'mathematics teacher identity' may be their only subject-specific teaching identity; but for elementary teachers and out-of-field teachers, it is only one of many subject-specific identities. In this sense, the term 'mathematics teaching identity', as applied by Hodges and Cady (2012), seems appropriate for all teachers who teach mathematics. Hence, we argue that there is a need to compare both cohorts and connect findings from both fields in a way that can inform and benefit both elementary and mathematics teachers. Indeed, their differences would be viable starting points for investigating and supporting the development of identities for all mathematics teachers. With these differences in mind, we need to acknowledge that research on mathematics-related teacher identity will always be as diverse as the teachers who teach mathematics.

\section{Linking the Research on Student and Teacher Identities}

Teacher identity has often been explored in isolation from student identity (see e.g. HeydMetzuyanim, Lutovac, \& Kaasila, 2016). If we agree that teacher identity is significant due to its direct link to teaching, and consequently, to students' learning and mathematical identities, then more empirical data regarding this linking process is needed. For example, while Clark et al. (2013), Leatham and Hill (2010) and Pipere and Mičule (2014) discussed this relationship, they approached it only through teachers' self-reports or researchers' own observations. Outside of the reviewed studies, and from the perspective of student identity, the benefit of examining student and teacher identities simultaneously has been demonstrated (e.g. Heyd-Metzuyanim, 2013). Future research could provide more empirical evidence in this area.

\section{Methodological considerations}

Another point to consider is methodology. Most of the studies we reviewed on mathematicsrelated teacher identity were small-scale case studies that used data sources such as interviews, autobiographies/narratives and observations (see also Darragh, 2016); however, Gujarati (2013) and Van Putten et al. (2014) clearly highlighted the need to examine both, data from self-reporting and actual practice. Hence, we suggest that greater emphasis be placed on observations of practice; perhaps video-data could provide new directions and deeper insights into teaching identity. Additionally, in relation to the disconnect between mathematics education research and general education research, we also suggest approaching 
both the identities of pre-service mathematics and non-specialist teachers within a single investigation, as examining these dissimilar cohorts may help to design better teachertraining methods.

\section{The Contextualization of the Research on Identity}

Lastly, based on our analysis of 40 studies, we also recommend that future research on mathematics-related teacher identity provide explicit and careful descriptions of its research subjects and contexts, taking into account the wide audience of many international journals. In our review, it was not always clear who the researchers were (mathematics specialists or generalists) nor their education backgrounds. For example, pre-service mathematics teacher education differs between countries. In some, education students are trained to be mathematics specialists only in the last phases of their studies, while in others, students enrol in a particular subject, such as mathematics, from the very beginning. Pre-service elementary teacher training might also differ greatly between countries, especially in relation to the amount and content of mathematics courses (e.g. Lutovac \& Kaasila, 2014). These issues were often insufficiently discussed in the literature but are arguably of central importance when studying mathematics-related teacher identity.

\section{Conclusion}

In conclusion, much has been explored in terms of mathematics-related teacher identity; however, based on our analysis of recent studies, we have several recommendations for future research. First, we call for a more balanced psychosocial theoretical perspective, one that gives equal consideration to both individual and social dimensions. This may also help to demonstrate a more explicit, empirical connection between identity, affect and cognition. Second, it would be beneficial for studies on mathematics-related teacher identity to incorporate more theoretical frameworks from the domain of general education. In other words, we strongly suggest that mathematics education researchers allow general education research to inform their work. This may bridge the gap between mathematics and education research and contribute to more coordination within the discipline as a whole. Third, we recommend that researchers apply systematic and versatile methodologies and integrate multiple sources of data, which would create a more holistic picture of teacher identity. Similarly, for the purposes of clarity and understanding, we call for more explicit descriptions of the contexts in which studies are conducted.

\section{References}

Andersson, A. (2011). A "curling teacher" in mathematics education: Teacher identities and pedagogy development. Mathematics Education Research Journal, 23(4), 437-454.

Beauchamp, C., \& Thomas, L. (2009). Understanding teacher identity: An overview of issues in the literature and implications for teacher education. Cambridge Journal of Education, 39(2), 175-189.

Beijaard, D., Meijer, P. C., \& Verloop, N. (2004). Reconsidering research on teachers' professional identity. Teaching and Teacher Education, 20(2), 107-128.

Beijaard, D., Verloop, N., \& Vermunt, J. D. (2000). Teachers' perceptions of professional identity: An exploratory study from a personal knowledge perspective. Teaching and Teacher Education, 16, 749-764.

Bennison, A. (2015). Developing an analytic lens for investigating identity as an embedderof-numeracy. Mathematics Education Research Journal, 27(1), 1-19. 
Bjuland, R., Cestari, M. L., \& Borgersen, H. E. (2012). Professional mathematics teacher identity: Analysis of reflective narratives from discourses and activities. Journal of Mathematics Teacher Education, 15(5), 405-424.

Black, L., Mendick, H., \& Solomon, Y. (Eds.) (2009). Mathematical relationships in education: Identities \& participation. New York, NY: Routledge.

Boaler, J. (2015). Mathematical mindsets: Unleashing students' potential through creative math, inspiring messages, and innovative teaching. San Francisco, CA: Jossey-Bass.

Boylan, M., \& Woolsey, I. (2015). Teacher education for social justice: Mapping identity spaces. Teaching and Teacher Education, 46, 62-71.

Brodie, K. (2011). Review of the book Mathematical relationships in education: Identities and participation, by L. Black, H. Mendick, \& Y. Solomon (Eds.). Educational Studies in Mathematics, 76(2), 237-241.

Brown, T., \& McNamara, O. (2011). Becoming a mathematics teacher: Identity and identifications. Dordrecht, The Netherlands: Springer.

Chval, K. B., Arbaugh, F., Lannin, J. K., van Garderen, D., Cummings, L., Estapa, A. T., \& Huey, M. E. (2010). The transition from experienced teacher to mathematics coach: Establishing a new identity. Elementary School Journal, 111(1), 191-216.

Chronaki, A., \& Matos, A. (2014). Technology use and mathematics teaching: Teacher change as discursive identity work. Learning, Media, and Technology, 39(1), 107125.

Clark, L. M., Badertscher, E. M., \& Napp, C. (2013). African American mathematics teachers as agents in their African American students' mathematics identity formation. Teachers College Record, 115(2), 1-36.

Cooper, K., \& Olson, M. R. (1996). The multiple 'I's' of teacher identity. In M. Kompf, W. R. Bond, D. Dworet, \& R. T. Boak (Eds.), Changing research and practice: Teachers' professionalism, identities, and knowledge (pp. 78-89). London: The Falmer Press.

Darragh, L. (2016). Identity research in mathematics education. Educational Studies in Mathematics, DOI 10.1007/s10649-016-9696-5.

de Freitas, E. (2008). Troubling teacher identity: Preparing mathematics teachers to teach for diversity. Teaching Education, 19(1), 43-55.

Di Martino, P., \& Zan, R. (2010). "Me and maths": Towards a definition of attitude grounded on students' narratives. Journal of Mathematics Teacher Education, 13(1), 27-48.

Drake, C., Spillane, J. P., \& Hufferd-Ackles, K. (2001). Storied identities: Teacher learning and subject-matter context. Journal of Curriculum Studies, 33(1), 1-23.

Essien, A. A. (2014). Examining opportunities for the development of interacting identities within pre-Service teacher education mathematics classrooms. Perspectives in Education, 32(3), 62-77.

Flores, M. A., \& Day, C. (2006). Contexts which shape and reshape new teachers' identities: A multiperspective study. Teaching and Teacher Education, 22, 219-232.

Gee, J. P. (2001). Identity as an analytic lens for research in education. In W. G. Secada (Ed.) Review of Research in Education, (Vol. 25, pp. 99-125). Washington, DC: American Educational Research Association.

Goos, M. (2005). A sociocultural analysis of the development of pre-service and beginning teachers' pedagogical identities as users of technology. Journal of Mathematics Teacher Education, 8(1), 35-59.

Goos, M. E., \& Bennison, A. (2008). Developing a communal identity as beginning teachers of mathematics: Emergence of an online community of practice. Journal of Mathematics Teacher Education, 11(1), 41-60. 
Grootenboer, P. J. (2006). Mathematics educators: Identity, beliefs, roles and ethical dilemmas. In P. Grootenboer, R. Zevenbergen, \& M. Chinnappan (Eds.), Identities, cultures and learning spaces: Proceedings of the 29th Annual Conference of the Mathematics Education Research Group of Australasia, (Vol. 1, pp. 270-277). Canberra, Australia: MERGA.

Grootenboer, P., \& Zevenbergen, R. (2008). Identity as a lens to understand learning mathematics: Developing a model. In M. Goos, R. Brown, \& K. Makar (Eds.) Proceedings of the 31st Annual Conference of the Mathematics Education Research Group of Australasia (pp. 243-244). Canberra, Australia: MERGA.

Gujarati, J. (2013). An "inverse" relationship between mathematics identities and classroom practices among early career elementary teachers: The impact of accountability. The Journal of Mathematical Behavior, 32(3), 633-648.

Hamachek, D. (1999). Effective teachers: What they do, how they do it, and the importance of self- knowledge. In R. P. Lipka \& T. M. Brinthaupt (Eds.), The role of self in teacher development (pp. 189-224). Albany, NY: State University of New York Press.

Heyd Metzuyanim, E. (2013). The co-construction of learning difficulties in mathematicsteacher-student interactions and their role in the development of a disabled mathematical identity. Educational Studies in Mathematics, 83(3), 341-368.

Heyd-Metzuyanim, E., Lutovac, S., \& Kaasila, R. (2016). Identity. In G. A. Goldin et al., Attitudes, Beliefs, Motivation and Identity in Mathematics Education: An Overview of the Field and Future Directions (ICME-13 Topical Surveys) (pp. 16-18). Springer.

Hobbs, L. (2012a). Teaching "out-of-field" as a boundary-crossing event: Factors shaping teacher identity. International Journal of Science and Mathematics Education, 11(2), 271-297.

Hobbs, L. (2012b). Examining the aesthetic dimensions of teaching: Relationships between teacher knowledge, identity, and passion. Teaching and Teacher Education, 28(5), $718-727$.

Hodges, T. E., \& Cady, J. A. (2012). Negotiating contexts to construct an identity as a mathematics teacher. Journal of Educational Research, 105(2), 112-122.

Hodgen, J., \& Askew, M. (2007). Emotion, identity, and teacher learning: Becoming a primary mathematics teacher. Oxford Review of Education, 33(4), 469-487.

Hossain, S., Mendick, H., \& Adler, J. (2013). Troubling "understanding mathematics indepth": Its role in the identity work of student-teachers in England. Educational Studies in Mathematics, 84(1), 35-48.

Izadinia, M. (2013). A review of research on student teachers' professional identity. British Educational Research Journal, 39(4), 694-713.

Jones, L., Brown, T., Hanley, U., \& McNamara, O. (2000). An enquiry into transitions: From being a 'learner of mathematics' to becoming a 'teacher of mathematics'. Research in Education, 63, 1-10.

Kaasila, R. (2007). Using narrative inquiry for investigating the becoming of a mathematics teacher. ZDM, 39, 205-213.

Kaasila, R., Hannula, M., Laine, A., \& Pehkonen, E. (2008). Socio-emotional orientations and teacher change. Educational Studies in Mathematics, 67(2), 111-123.

Kaasila, R., Hannula, M. S., \& Laine, A. (2012). "My personal relationship towards mathematics has necessarily not changed but..." Analyzing pre-service teachers' mathematical identity talk. International Journal of Science and Mathematics Education, 10(4), 975-995.

Kasten, S. E., Austin, C., \& Jackson, C. (2014). Am I a mathematics teacher who teaches middle grades or a middle grades teacher who teaches mathematics? Untangling the 
multiple identities of pre-service teachers. Middle Grades Research Journal, 9(2), 127-140.

Leatham, K. R., \& Hill, D. S. (2010). Exploring our complex math identities. Mathematics Teaching in the Middle School, 16(4), 224-231.

Lerman, S. (2013). Theories in practice: Mathematics teaching and mathematics teacher education. ZDM, 45(4), 623-631.

Llewellyn, A. (2009). "Gender games": A post-structural exploration of the prospective teacher, mathematics, and identity. Journal of Mathematics Teacher Education, 12(6), 411-426.

Lutovac, S., \& Kaasila, R. (2011). Beginning a pre-service teacher's mathematical identity work through narrative rehabilitation and bibliotherapy. Teaching in Higher Education, 16(2), 225-236.

Lutovac, S., \& Kaasila, R. (2012). Dialogue between past and future mathematical identities. Nordic Studies in Mathematics Education, 17(3-4), 125-139.

Lutovac, S., \& Kaasila, R. (2014). Pre-service teachers' future-oriented mathematical identity work. Educational Studies in Mathematics, 85(1), 129-142.

Ma, J. Y., \& Singer-Gabella, M. (2011). Learning to teach in the figured world of reform mathematics: Negotiating new models of identity. Journal of Teacher Education, 62(1), 8-22.

McCulloch, A. W, Marshall, P. L., DeCuir-Gunby, J. T., \& Caldwell, T. S. (2013). Math autobiographies: A window into teachers' identities as mathematics learners. School Science and Mathematics, 113(8), 380-389.

Neumayer Depiper, J. (2013). Teacher identity work in mathematics teacher education. For the Learning of Mathematics, 33(1), 9-15.

Owens, K. (2008). Identity as a mathematical thinker. Mathematics Teacher Education and Development, 9, 36-50.

Owens, K. (2014). The impact of a teacher education culture-based project on identity as a mathematically thinking teacher. Asia-Pacific Journal of Teacher Education, 42(2), 186-207.

Pausigere, P., \& Graven, M. (2013). Unveiling the South African official primary mathematics teacher pedagogic identity. Perspectives in Education (Special Issue: Primary Mathematics: Addressing the Crisis), 31(3), 19-33.

Pipere, A., \& Mičule, I. (2014). Mathematical identity for a sustainable future: An interpretative phenomenological analysis. Journal of Teacher Education for Sustainability, 16(1), 5-31.

Rodgers, C., \& Scott, K. (2008). The development of the personal self and professional identity in learning to teach. In M. Cochran-Smith, S. Feiman-Nemser, D. J. McIntyre, \& K. E. Demers (Eds.), Handbook of research on teacher education: Enduring questions and changing contexts (pp. 732-755). New York, NY: Routledge.

Sfard, A., \& Prusak, A. (2005). Telling identities: In search of an analytic tool for investigating learning as a culturally shaped activity. Educational Researcher, 34(4), $14-22$.

Skog, K., \& Andersson, A. (2015). Exploring positioning as an analytical tool for understanding becoming mathematics teachers' identities. Mathematics Education Research Journal, 27(1), 65-82.

Skott, J., van Zoest, L., \& Gellert, U. (2013). Theoretical frameworks in research on and with mathematics teachers. ZDM, 45(4), 501-505.

Spitler, E. (2012). From resistance to advocacy for math literacy: One teacher's literacy identity transformation. Journal of Adolescent \& Adult Literacy, 55(4), 306-315. 
Spillane, J. P. (2000). A fifth-grade teacher's reconstruction of mathematics and literacy teaching: Exploring interactions among identity, learning, and subject matter. Elementary School Journal, 100(4), 307-330.

van Putten, S., Stols, G., \& Howie, S. (2014). Do prospective mathematics teachers teach who they say they are? Journal of Mathematics Teacher Education, 17(4), 369-392.

van Zoest, L. R., \& Bohl, J. V. (2005). Mathematics teacher identity: A framework for understanding secondary school mathematics teachers' learning through practice. Teacher Development, 9(3), 315-345.

Walshaw, M. (2013). Post-structuralism and ethical practical action: Issues of identity and power. Journal for Research in Mathematics Education, 44(1), 100-118.

Wassell, B. A. (2006). The type of teacher I don't want to be: Constructing teacher identity through converse descriptions and student voice. Teacher Education and Practice, 19(2), 149-163.

Watson, C. (2006). Narratives of practice and the construction of identity in teaching. Teachers and Teaching: Theory and Practice, 12(5), 509-526.

Wenger, E. (1998). Communities of practice: Learning, meaning, and identity. Cambridge, UK: Cambridge University Press.

Williams, J. (2011). Teachers telling tales: The narrative mediation of professional identity. Research in Mathematics Education, 13(2), 131-142.

Woolhouse, C., \& Cochrane, M. (2015). Educational policy or practice? Traversing the conceptual divide between subject knowledge, pedagogy, and teacher identity in England. European Journal of Teacher Education, 38(1), 87-101.

\section{Appendix}

Table 1

Selected studies included in the analysis

\begin{tabular}{|c|c|c|c|c|}
\hline Study & Topic & Subjects & $\begin{array}{l}\text { Examples of } \\
\text { research that } \\
\text { informed the } \\
\text { theoretical } \\
\text { framework of the } \\
\text { study }\end{array}$ & $\begin{array}{l}\text { Context } \\
\text { of the } \\
\text { study }\end{array}$ \\
\hline $\begin{array}{l}\text { Bennison } \\
(2015)\end{array}$ & $\begin{array}{l}\text { The development of } \\
\text { 'identity as an embedder- } \\
\text { of-numeracy' }\end{array}$ & $\begin{array}{l}\text { Theoretical } \\
\text { discussion of } \\
\text { teacher identities }\end{array}$ & $\begin{array}{l}\text { Gee (2001), Sfard } \\
\& \text { Prusak (2005), } \\
\text { Wenger }(1998)\end{array}$ & Australia \\
\hline $\begin{array}{l}\text { Woolhouse \& } \\
\text { Cochrane } \\
(2015)\end{array}$ & $\begin{array}{l}\text { (Re)construction of } \\
\text { teacher identity through } \\
\text { engagement with } \\
\text { education policy }\end{array}$ & $\begin{array}{l}\text { Mathematics, } \\
\text { chemistry and } \\
\text { physics teacher } \\
\text { trainees }\end{array}$ & $\begin{array}{l}\text { J. Lave and E. } \\
\text { Wenger }\end{array}$ & $U K$ \\
\hline $\begin{array}{l}\text { Skog \& } \\
\text { Andersson } \\
(2015)\end{array}$ & $\begin{array}{l}\text { Positioning as a way } \\
\text { of understanding } \\
\text { teacher identity } \\
\text { development }\end{array}$ & $\begin{array}{l}\text { Pre-service } \\
\text { mathematics } \\
\text { teachers }\end{array}$ & $\begin{array}{l}\text { Socio-political } \\
\text { perspective; } \\
\text { P. Valero, } \\
\text { R. Gutierrez }\end{array}$ & Sweden \\
\hline $\begin{array}{l}\text { Boylan \& } \\
\text { Woolsey } \\
(2015)\end{array}$ & $\begin{array}{l}\text { Theorising social } \\
\text { justice teacher } \\
\text { education and teacher } \\
\text { identity }\end{array}$ & $\begin{array}{l}\text { In-service } \\
\text { mathematics } \\
\text { teachers }\end{array}$ & $\begin{array}{l}\text { Positioning } \\
\text { theory; } \\
\text { G. Deleuze and } \\
\text { G. Guattari }\end{array}$ & $U K$ \\
\hline
\end{tabular}




\begin{tabular}{|c|c|c|c|c|}
\hline Essien (2014) & $\begin{array}{l}\text { Teacher education } \\
\text { opportunities for the } \\
\text { development of multiple } \\
\text { identities }\end{array}$ & $\begin{array}{l}\text { Pre-service } \\
\text { mathematics } \\
\text { teachers }\end{array}$ & Wenger (1998) & $\begin{array}{l}\text { South } \\
\text { Africa }\end{array}$ \\
\hline Owens (2014) & $\begin{array}{l}\text { The influence of } \\
\text { mathematics and culture } \\
\text { on teacher identity } \\
\text { development }\end{array}$ & $\begin{array}{l}\text { Pre-service and } \\
\text { in-service } \\
\text { mathematics and } \\
\text { elementary } \\
\text { teachers }\end{array}$ & $\begin{array}{l}\text { Cultural-historical } \\
\text { activity theory }\end{array}$ & Australia \\
\hline $\begin{array}{l}\text { Pipere \& } \\
\text { Mičule (2014) }\end{array}$ & $\begin{array}{l}\text { The dynamics of } \\
\text { mathematical identity }\end{array}$ & $\begin{array}{l}\text { In-service } \\
\text { mathematics } \\
\text { teachers }\end{array}$ & $\begin{array}{l}\text { Dialogical self- } \\
\text { theory; Wenger } \\
\text { (1998) }\end{array}$ & Latvia \\
\hline $\begin{array}{l}\text { Chronaki \& } \\
\text { Matos (2014) }\end{array}$ & $\begin{array}{l}\text { Teacher identity work } \\
\text { and the role of ICT }\end{array}$ & $\begin{array}{l}\text { In-service } \\
\text { mathematics } \\
\text { teachers }\end{array}$ & $\begin{array}{l}\text { E. Laclau and C. } \\
\text { Mouffe, } \\
\text { M. Foucault }\end{array}$ & Greece \\
\hline $\begin{array}{l}\text { van Putten, } \\
\text { Stols \& } \\
\text { Howie (2014) }\end{array}$ & $\begin{array}{l}\text { Incongruities between } \\
\text { self-perceived and } \\
\text { actualised teacher } \\
\text { identities }\end{array}$ & $\begin{array}{l}\text { Pre-service } \\
\text { mathematics } \\
\text { teachers }\end{array}$ & $\begin{array}{l}\text { Beijaard, } \\
\text { Verloop \& } \\
\text { Vermunt, } \\
\text { (2000), Flores } \\
\text { \& Day (2006) }\end{array}$ & $\begin{array}{l}\text { South } \\
\text { Africa }\end{array}$ \\
\hline $\begin{array}{l}\text { Kasten, } \\
\text { Austin \& } \\
\text { Jackson } \\
(2014)\end{array}$ & $\begin{array}{l}\text { Middle school teachers' } \\
\text { multiple identities }\end{array}$ & $\begin{array}{l}\text { Pre-service } \\
\text { middle school } \\
\text { teachers }\end{array}$ & $\begin{array}{l}\text { Beijaard, Meijer \& } \\
\text { Verloop (2004), } \\
\text { Gee (2001), Sfard \& } \\
\text { Prusak (2005) }\end{array}$ & $U S A$ \\
\hline $\begin{array}{l}\text { Lutovac \& } \\
\text { Kaasila } \\
(2014)\end{array}$ & $\begin{array}{l}\text { Contextuality of pre- } \\
\text { service teachers' } \\
\text { mathematical identity } \\
\text { work }\end{array}$ & $\begin{array}{l}\text { Pre-service } \\
\text { elementary } \\
\text { teachers }\end{array}$ & $\begin{array}{l}\text { P. Ricoeur; H. } \\
\text { Markus and P. } \\
\text { Nurius' concept of } \\
\text { possible selves }\end{array}$ & Finland \\
\hline $\begin{array}{l}\text { Gujarati } \\
(2013)\end{array}$ & $\begin{array}{l}\text { Relationship between } \\
\text { teachers' mathematics } \\
\text { identities and their } \\
\text { teaching practices }\end{array}$ & $\begin{array}{l}\text { In-service } \\
\text { elementary } \\
\text { teachers }\end{array}$ & $\begin{array}{l}\text { Gee (2001), Sfard } \\
\& \text { Prusak (2005), } \\
\text { Wenger (1998) }\end{array}$ & $U S A$ \\
\hline $\begin{array}{l}\text { Clark, } \\
\text { Badertscher \& } \\
\text { Napp (2013) }\end{array}$ & $\begin{array}{l}\text { African-American } \\
\text { teachers' practices in } \\
\text { supporting students' } \\
\text { identity development }\end{array}$ & $\begin{array}{l}\text { In-service } \\
\text { mathematics } \\
\text { teachers }\end{array}$ & D. B. Martin & USA \\
\hline $\begin{array}{l}\text { Pausigere \& } \\
\text { Graven (2013) }\end{array}$ & $\begin{array}{l}\text { South African primary } \\
\text { mathematics education } \\
\text { curricula and projected } \\
\text { teacher identities }\end{array}$ & Curricula analysis & B. Bernstein & $\begin{array}{l}\text { South } \\
\text { Africa }\end{array}$ \\
\hline $\begin{array}{l}\text { Neumayer- } \\
\text { Depiper } \\
(2013)\end{array}$ & $\begin{array}{l}\text { Facilitating identity } \\
\text { work in teacher } \\
\text { education }\end{array}$ & $\begin{array}{l}\text { Pre-service } \\
\text { elementary } \\
\text { teachers }\end{array}$ & $\begin{array}{l}\text { J. Butler, } \\
\text { de Freitas (2008) }\end{array}$ & $U S A$ \\
\hline $\begin{array}{l}\text { Hossain, } \\
\text { Mendick \& } \\
\text { Adler (2013) }\end{array}$ & $\begin{array}{l}\text { Identity work in the } \\
\text { mathematics } \\
\text { enhancement course }\end{array}$ & $\begin{array}{l}\text { Pre-service } \\
\text { mathematics } \\
\text { teachers }\end{array}$ & $\begin{array}{l}\text { M. Foucault; } \\
\text { J. Butler }\end{array}$ & $U K$ \\
\hline $\begin{array}{l}\text { Walshaw } \\
(2013)\end{array}$ & $\begin{array}{l}\text { The role of power in } \\
\text { informing one's } \\
\text { identity construction }\end{array}$ & $\begin{array}{l}\text { Pre-service } \\
\text { mathematics } \\
\text { teachers and } \\
\text { secondary } \\
\text { school students }\end{array}$ & M. Foucault & $\begin{array}{l}\text { New } \\
\text { Zealand }\end{array}$ \\
\hline
\end{tabular}


McCulloch,

Marshall,

DeCuir-

Gunby,

Caldwell \&

Ticola (2013)

\begin{tabular}{|c|c|c|c|c|}
\hline $\begin{array}{l}\text { Bjuland, } \\
\text { Cestari \& } \\
\text { Borgersen } \\
(2012)\end{array}$ & $\begin{array}{l}\text { Teacher identity } \\
\text { development through } \\
\text { reflective narratives }\end{array}$ & $\begin{array}{l}\text { In-service } \\
\text { elementary } \\
\text { teachers }\end{array}$ & $\begin{array}{l}\text { Sfard \& Prusak } \\
(2005)\end{array}$ & Norway \\
\hline $\begin{array}{l}\text { Hobbs } \\
(2012 a)\end{array}$ & $\begin{array}{l}\text { The role of contextual } \\
\text { factors, particularly } \\
\text { that of a subject } \\
\text { context in teachers' } \\
\text { identities }\end{array}$ & $\begin{array}{l}\text { In-service math } \\
\text { and science } \\
\text { teachers }\end{array}$ & $\begin{array}{l}\text { Beijaard et al. } \\
(2004) \text {, } \\
\text { Beauchamp \& } \\
\text { Thomas (2009), } \\
\text { M. Connelly \& J. } \\
\text { Clandinin }\end{array}$ & Australia \\
\hline $\begin{array}{l}\text { Hobbs } \\
(2012 b)\end{array}$ & $\begin{array}{l}\text { The influence of the } \\
\text { subject context on } \\
\text { teaching approaches }\end{array}$ & $\begin{array}{l}\text { In-service math } \\
\text { and/or science } \\
\text { teachers }\end{array}$ & $\begin{array}{l}\text { J. Dewey's } \\
\text { framework of } \\
\text { aesthetic } \\
\text { experience; } \\
\text { Beijaard et al. } \\
(2004)\end{array}$ & Australia \\
\hline
\end{tabular}

\begin{tabular}{|c|c|c|c|c|}
\hline Spitler (2012) & $\begin{array}{l}\text { 'Literacy } \\
\text { identity'development and } \\
\text { change }\end{array}$ & $\begin{array}{l}\text { Pre-service } \\
\text { mathematics } \\
\text { teachers }\end{array}$ & $\begin{array}{l}\text { Wenger (1998), } \\
\text { J. Gee }\end{array}$ & $U S A$ \\
\hline $\begin{array}{l}\text { Hodges \& } \\
\text { Cady }(2012)\end{array}$ & $\begin{array}{l}\text { Contextuality of teacher } \\
\text { identity development }\end{array}$ & $\begin{array}{l}\text { In-service grade } \\
\text { school teachers }\end{array}$ & $\begin{array}{l}\text { Gee (2001), Sfard } \\
\text { \& Prusak (2005), } \\
\text { Wenger (1998) }\end{array}$ & $U S A$ \\
\hline $\begin{array}{l}\text { Kaasila, } \\
\text { Hannula \& } \\
\text { Laine (2012) }\end{array}$ & $\begin{array}{l}\text { Teacher identity } \\
\text { development and change } \\
\text { through exploration of } \\
\text { identity talk }\end{array}$ & $\begin{array}{l}\text { Pre-service } \\
\text { elementary } \\
\text { teachers }\end{array}$ & $\begin{array}{l}\text { Discursive } \\
\text { psychology; } \\
\text { D. Edwards; J. } \\
\text { Potter }\end{array}$ & Finland \\
\hline $\begin{array}{l}\text { Ma \& Singer- } \\
\text { Gabella } \\
(2011)\end{array}$ & $\begin{array}{l}\text { Development of possible } \\
\text { identities within the } \\
\text { figured words }\end{array}$ & $\begin{array}{l}\text { Pre-service } \\
\text { elementary } \\
\text { teachers }\end{array}$ & $\begin{array}{l}\text { D. Holland and } \\
\text { colleagues }\end{array}$ & $U S A$ \\
\hline $\begin{array}{l}\text { Williams } \\
(2011)\end{array}$ & $\begin{array}{l}\text { The role of biographical } \\
\text { narrative in teacher } \\
\text { identity (work) }\end{array}$ & $\begin{array}{l}\text { In-service } \\
\text { mathematics } \\
\text { teachers }\end{array}$ & $\begin{array}{l}\text { D. Holland and } \\
\text { colleagues }\end{array}$ & $U K$ \\
\hline $\begin{array}{l}\text { Andersson } \\
(2011)\end{array}$ & $\begin{array}{l}\text { Teachers' identity } \\
\text { shifts in the face of } \\
\text { changing teaching } \\
\text { practices }\end{array}$ & $\begin{array}{l}\text { In-service } \\
\text { mathematics } \\
\text { teachers }\end{array}$ & $\begin{array}{l}\text { Socio-cultural- } \\
\text { political } \\
\text { perspective; } \\
\text { Sfard \& Prusak } \\
(2005), \\
\text { P. Valero }\end{array}$ & Sweden \\
\hline $\begin{array}{l}\text { Lutovac \& } \\
\text { Kaasila } \\
(2011)\end{array}$ & $\begin{array}{l}\text { The influence of } \\
\text { narrative tools on teacher } \\
\text { identity work }\end{array}$ & $\begin{array}{l}\text { One pre-service } \\
\text { elementary } \\
\text { teacher }\end{array}$ & $\begin{array}{l}\text { P. Ricoeur; Beijaard } \\
\text { et al. (2004) }\end{array}$ & Finland \\
\hline $\begin{array}{l}\text { Leatham \& } \\
\text { Hill (2010) }\end{array}$ & $\begin{array}{l}\text { The role of reflection in } \\
\text { students' and teachers' } \\
\text { identities }\end{array}$ & $\begin{array}{l}\text { In-service } \\
\text { mathematics } \\
\text { teachers and } \\
\text { students }\end{array}$ & $\begin{array}{l}\text { Research on beliefs } \\
\text { in (mathematics) } \\
\text { education }\end{array}$ & $U S A$ \\
\hline
\end{tabular}

In-service $\quad$ Drake et al. (2001), USA $\begin{array}{lll}\text { autobiographical } & \text { elementary } & \text { Sfard \& Prusak } \\ \text { memories of being } & \text { teachers } & \text { (2005), etc. }\end{array}$ $\begin{array}{lll}\text { autobiographical } & \text { elementary } & \text { Sfard \& Prusak } \\ \text { memories of being } & \text { teachers } & \text { (2005), etc. }\end{array}$ mathematics learners . 


\begin{tabular}{|c|c|c|c|c|}
\hline $\begin{array}{l}\text { Llewellyn } \\
(2009)\end{array}$ & $\begin{array}{l}\text { Teacher identity } \\
\text { development and } \\
\text { conflicting and } \\
\text { gendered discourses }\end{array}$ & $\begin{array}{l}\text { Pre-service } \\
\text { elementary } \\
\text { teachers }\end{array}$ & M. Foucault & $U K$ \\
\hline $\begin{array}{l}\text { Goos \& } \\
\text { Bennison } \\
(2008)\end{array}$ & $\begin{array}{l}\text { The role of online } \\
\text { communities of practice } \\
\text { on teacher identity } \\
\text { development }\end{array}$ & $\begin{array}{l}\text { Pre-service } \\
\text { mathematics } \\
\text { teachers }\end{array}$ & Wenger (1998) & Australia \\
\hline Owens (2008) & $\begin{array}{l}\text { The development of } \\
\text { 'identity as a } \\
\text { mathematical thinker' }\end{array}$ & $\begin{array}{l}\text { Pre-service } \\
\text { elementary } \\
\text { teachers }\end{array}$ & Wenger (1998) & Australia \\
\hline $\begin{array}{l}\text { de Freitas } \\
(2008)\end{array}$ & $\begin{array}{l}\text { Contextuality of } \\
\text { teacher identity } \\
\text { development and } \\
\text { issues of social justice }\end{array}$ & $\begin{array}{l}\text { Pre-service } \\
\text { mathematics } \\
\text { teachers }\end{array}$ & e.g., M. Walshaw & $U S A$ \\
\hline $\begin{array}{l}\text { Kaasila, } \\
\text { Hannula, } \\
\text { Laine \& } \\
\text { Pehkonen } \\
(2008)\end{array}$ & $\begin{array}{l}\text { The change of pre- } \\
\text { service teachers' views } \\
\text { of mathematics during } \\
\text { mathematics methods } \\
\text { courses }\end{array}$ & $\begin{array}{l}\text { Pre-service } \\
\text { elementary } \\
\text { teachers }\end{array}$ & $\begin{array}{l}\text { Research on affect } \\
\text { in mathematics } \\
\text { education }\end{array}$ & Finland \\
\hline $\begin{array}{l}\text { Hodgen \& } \\
\text { Askew (2007) }\end{array}$ & $\begin{array}{l}\text { The role of emotions in } \\
\text { teacher identity } \\
\text { development }\end{array}$ & $\begin{array}{l}\text { In-service } \\
\text { elementary } \\
\text { teachers }\end{array}$ & Wenger (1998) & $U K$ \\
\hline $\begin{array}{l}\text { Wassell } \\
(2006)\end{array}$ & $\begin{array}{l}\text { The role of student voice } \\
\text { in teacher identity } \\
\text { development }\end{array}$ & $\begin{array}{l}\text { Pre-service } \\
\text { mathematics } \\
\text { teachers }\end{array}$ & $\begin{array}{l}\text { Sfard \& Prusak } \\
(2005)\end{array}$ & USA \\
\hline Goos (2005) & $\begin{array}{l}\text { The development of } \\
\text { pedagogical identity in } \\
\text { the context of teaching } \\
\text { with technology }\end{array}$ & $\begin{array}{l}\text { In-service } \\
\text { mathematics } \\
\text { teachers }\end{array}$ & J. Valsiner & Australia \\
\hline $\begin{array}{l}\text { van Zoest \& } \\
\text { Bohl (2005) }\end{array}$ & $\begin{array}{l}\text { Developing a theoretical } \\
\text { framework of } \\
\text { 'mathematics teacher } \\
\text { identity' }\end{array}$ & $\begin{array}{l}\text { Theoretical } \\
\text { discussion of pre- } \\
\text { service } \\
\text { mathematics } \\
\text { teachers }\end{array}$ & $\begin{array}{l}\text { J. Lave \& E. } \\
\text { Wenger, Wenger } \\
(1998)\end{array}$ & $U S A$ \\
\hline $\begin{array}{l}\text { Drake, } \\
\text { Spillane \& } \\
\text { Hufferd- } \\
\text { Ackles (2001) }\end{array}$ & $\begin{array}{l}\text { The role of subject } \\
\text { matter in teacher identity } \\
\text { development within } \\
\text { narratives }\end{array}$ & $\begin{array}{l}\text { In-service } \\
\text { elementary } \\
\text { teachers }\end{array}$ & D. P. McAdams & $U S A$ \\
\hline $\begin{array}{l}\text { Spillane } \\
(2000)\end{array}$ & $\begin{array}{l}\text { Interaction between } \\
\text { teacher identity and } \\
\text { subject matter }\end{array}$ & $\begin{array}{l}\text { In-service } \\
\text { elementary } \\
\text { teachers }\end{array}$ & $\begin{array}{l}\text { e.g., M. Connelly } \\
\text { and J. Clandinin }\end{array}$ & $U S A$ \\
\hline
\end{tabular}

